\title{
Research on High Density Oil-Based Drilling Fluid and Application in the Southern Edge of Junggar Basin, China
}

\author{
Yidi Wang1,2, Yuezhi Wang ${ }^{*}$, Biao Ran ${ }^{3}$, Pengyun Xing ${ }^{3}$, Xiaoliang Xin ${ }^{3}$, Yi Li ${ }^{3}$ \\ ${ }^{1}$ College of Petroleum Engineering, Yangtze University, Wuhan, China \\ ${ }^{2}$ Faculty of Engineering, China University of Geoscience, Wuhan, China \\ ${ }^{3}$ Exploration Company, Xinjiang Oilfield Corporation of Petrochina, Karamay, China \\ Email: *yzwang@yangtzeu.edu.cn
}

How to cite this paper: Wang, Y.D., Wang, Y.Z., Ran, B., Xing, P.Y., Xin, X.L. and Li, Y. (2018) Research on High Density Oil-Based Drilling Fluid and Application in the Southern Edge of Junggar Basin, China. Open Journal of Yangtze Gas and Oil, 3, 253-262.

https://doi.org/10.4236/ojogas.2018.34022

Received: January 8, 2018

Accepted: October 23, 2018

Published: October 26, 2018

Copyright $\odot 2018$ by authors and Scientific Research Publishing Inc. This work is licensed under the Creative Commons Attribution International License (CC BY 4.0).

http://creativecommons.org/licenses/by/4.0/

\begin{abstract}
The southern edge of the Junggar basin has broad exploration potential. However, high-frequency complex drilling accidents in this area lead to the reduction of the average drilling speed and the extension of the drilling cycle. The main geological reason is that this area was affected by the process and developed high and steep geological structure. The nappe formation with a large dip angle and poor stability developed along faults. The major rock type of this $\mathrm{E}_{2-3}$ a formation is mud-stone which has strong water sensitivity and can be hydrated and dispersed easily, which leads to the wellbore shrinkage and the borehole collapse. In order to improve the drilling speed in the southern edge of the Junggar basin and accelerate the exploration and development process, the drilling fluids associated with drilling problems in this area were investigated in this paper by combing the geological information and historical drilling records. Because of the special characteristics of this formation, it is concluded that the water-based drilling fluids previously used in this area are not suitable to solve the complex drilling conditions; a high density oil-based drilling fluid system has been developed for this area by conducting studies in the laboratory initially and being tested in the field later. In addition, its rheology, stability and pollution resistance performances were evaluated. Results show that, the rheology, the stability and pollution resistance capacities of the drilling fluid satisfy the drilling requirements. The fluid was applied in well $\mathrm{H} 101$ and the results show that the ROP of section $311.1 \mathrm{~mm}$ of the well was increased by $763 \%$ compared to the wells drilled in the same area and the total drilling time of well H101 was reduced by more than $80 \%$, which was a historic breakthrough of the drilling speed in the southern edge.
\end{abstract}




\section{Keywords}

Junggar Basin, Southern Edge, High Steep Structure, High Density Oil-Based Drilling Fluid System

\section{Introduction}

The southern edge of the Junggar Basin in Xinjiang of China is one of the areas with abundant oil and gas reservoir. The southern edge is in the Piedmont of the northern Tianshan Mountain, affected by the tectonic movement and the fold formed in the plane. This area, which has great exploitation potential, was ideal for oil and gas gathering. However, the geological conditions in this area are very complex [1] [2]. Affected by the tectonic process, the middle-upper part comes with big dip angles and fault repetition of the old and new strata, which leads to the fragmented formation with poor stability. In the middle-down part, the hard brittle shale with nature fractures and strong water sensitivity could easily cause the shale swelling, the borehole collapse and the borehole shrinkage. Among the formations, the $\mathrm{E}_{2-3} \mathrm{a}$ formation is the worst. The lower part of the formation comes with the high stress and abnormal high pressure, thus, the high density drilling fluid is needed to balance the formation pressure during the drilling.

Because of the complex geological conditions in the Southern Edge region, drilling problems occur frequently during the drilling in this area. Low drilling speed, long drilling cycle, and high cost are typical constraints for the exploitation activities in this area. The water-based, PRT-organic salt drilling fluid system was mainly used in the past in this area, which leads to the shale swelling. Cuttings disperse in the drilling mud easily, which alters the mud properties. Complicated drilling incidents happened at a high frequency. This paper aims to reduce drilling problems, improve the drilling speed, cut the cost, and accelerate the exploration progress by studying the application of oil-based drilling fluid technology in the southern edge.

\section{Geological Characters and Drilling Fluid Difficulties}

\subsection{Geological Characters}

According to the data from 66 wells drilled in the southern edge area between 1996-2015, 44 wells (66.7\%) encountered different drilling incidents. Data from the wells drilled during the recent 5 years shows that the average Rate of Penetration (ROP) is lower than $3 \mathrm{~m} / \mathrm{h}$, and the average drilling cycle is above 100 days. The complex borehole problems, the high accident rate and the low ROP largely extended the drilling cycle and limited the drilling activities. The geological characters of this area are shown below:

1) Affected by the sedimentation and rock characteristics, the formation rock is sensitive to water. The analysis results of the formation $\mathrm{E}_{2-3} \mathrm{a}$ in the southern edge show that the major minerals components include illite and smectite. The 
content of smectite is above $40 \%$, clay minerals is above $30 \%$ (the maximum is $70 \%$ ), which indicates that there is a large amount of water sensitive clay in the formation $\mathrm{E}_{2-3}$ a.

2) Affected by the high horizontal stress from the Piedmont tectonic, the maximum horizontal stress is higher than the overburden pressure. The pressure gradient is very steep (with maximum is above $2.50 \mathrm{~g} / \mathrm{cm}^{3}$ ), which indicates that the area belongs to the high pressure and extreme high pressure category.

3) The broken nappe, and the high steep and weak bond between layers can easily cause the borehole instability. Because of the nappe extrusion and the tectonic movement, many tectonics come with faults with large dip angles, broken faults, and micro fracture. Many drilling accidents, such as the lost of the circulation, the borehole collapse and the drill pipe stuck, are likely to happen in this kind of formations.

4) The coexistence of high pressure and low pressure at the same well can easily lead to the lost circulation. Due to the existence of the unconformity plane, the low pressure layer, and the different pore pressure coefficient in the same well, the lost circulation, the blow-out, the borehole collapse, and the drill pipe stuck are very likely to happen. Additionally, there is not enough information to predict the pore pressure accurately, and the drilling fluid design is extremely difficult.

And the lithology analysis of the region is shown in Table 1. Based on the analysis results, it can be seen that the major clay components of the formation in the Southern Edge region are the mixture of illite and smectite, and the fraction of kaolinite is larger than $40 \%$. The content fraction of clay in the formation is larger than $30 \%$ (maximum 70\%). Results indicate that the formation in this region has a significant amount of water sensitive components, which increases the difficulties during the drilling in this region.

Table 1. Lithology analysis of Anjihaihe $\left(\mathrm{E}_{2-3} \mathrm{a}\right)$ of southern margin.

\begin{tabular}{cccccccc}
\hline \multirow{2}{*}{ Depth/m } & Lithology & \multicolumn{5}{c}{ Clay mineral analysis/\% } \\
\cline { 3 - 7 } & & K & I & C & I/S & S & Total \\
\hline Surface rock & Grey mud stone & 8 & 23 & 8 & 61 & 45 & 70 \\
$2480-2550$ & Dark brown sand stone & 5 & 22 & 6 & 67 & 40 & 57 \\
$2850-2855$ & Dark brown sand stone & 2 & 28 & 2 & 68 & 40 & 39 \\
$2994-3005$ & Tanned sand stone & 8 & 25 & 6 & 61 & 40 & 57 \\
$3040-3045$ & Tanned mud stone & 2 & 32 & 2 & 64 & 40 & 37 \\
\hline
\end{tabular}

Notes: $\mathrm{K} —$ kaolinite, I—illite, $\mathrm{C}$-chlorite, S—smectite, I/S—illite and smectite mixed rock.

\subsection{Difficulties in Drilling Fluid Design}

Because of the special characteristics of the formation $\mathrm{E}_{2-3} \mathrm{a}$, there are numerous difficulties in choosing proper drilling fluids, which can be listed below:

1) Strong water sensitivity results in severe dispersion of mudstone. The direct 
hazards caused by strong water sensitivity include the wellbore shrinkage, the collapse caused by shale swelling and it is difficult to control the rheological property of drilling fluids due to the hydrate dispersion of the clay in the drilled cuttings. The key point to drill wells successfully in the southern edge is the drilling fluid technology. In order to maintain the borehole stability, both physical support and chemical inhibition are needed.

2) High density, ultra-high density drilling fluid is needed to manage high stress, high pressure and ultrahigh pressure. But the rheology, the filtration loss of mud and other behaviors are difficult to control because of the high solid content. The Piedmont tectonic fault tectonic stress is strong, especially in the stress concentrated area. The stress release can easily cause downhole drilling problems such as the wellbore collapse, the wellbore shrinkage, and the drill pipe sticking. Due to high formation stress, high strata dip and strong formation hydration ability, the stabilizing wellbore needs high density mud. However, high density mud can lead to extremely slow ROP and long drilling cycle, which increases the exposure time of the formation to the drilling fluids.

3) The broken nappe, high steep and weak bond between layers can easily cause the borehole instability, which are the main reasons for drill pipe sticking and the sticking in the formation $\mathrm{E}_{2-3} \mathrm{a}$. It is difficult to regulate, maintain and manage the performance of high density drilling mud. The filtration loss, rheology and rejection capability are difficult to achieve simultaneously, and the maintenance and disposal costs of the drilling fluids are very high.

\section{High Density Oil-Based Drilling Fluid Technology}

Because of the strong water sensitivity of formation $E_{2-3} \mathrm{a}$ in the southern edge, drilling problems occurred frequently during the use of the water-based drilling fluids. In 2015, during drilling fluid design process, oil-based drilling fluids with strong inhibition, strong sealing and strong lubrication were used to replace the water-based drilling fluids used in the past [3] [4] [5] [6].

\subsection{Formula and Basic Properties}

According to the results of the laboratory study, the formula of the Oil-based drilling fluid used in the $311.1 \mathrm{~mm}$ hole section in well $\mathrm{H} 101$ is determined as:

$54 \%$ diesel $(0 \#)+7 \%$ TYODF -301 (primary emulsion) $+4 \%$ TYODF -401 (auxiliary emulsion) $+5 \%$ TYODF -501 (wetting agent) $+2 \%$ TYODF -601 (viscosifying agent) $+10 \%$ TYODF -201 (loss control agent) $+4 \%$ YX (blocking agent, 600 mesh) $+4 \%$ YX (blocking agent, above 800 mesh) $+4.8 \%$ water + $1.8 \%$ calcium chloride $+4 \%$ TYODF -801 (lime) + high density baria.

All the additives were acquired from Xuecheng Technology Company LLC (Hubei, China).

According to the analysis of drilling data from adjacent wells [7] [8] [9], the performance of oil-based drilling fluid for the $311.1 \mathrm{~mm}$ hole section should meet the requirements in Table 2. 
Table 2. The basic properties of the high density oil-based drilling fluid.

\begin{tabular}{|c|c|c|c|c|c|c|c|c|c|}
\hline \multirow{2}{*}{$\begin{array}{l}\text { Density/ } \\
\left(\mathrm{g} \cdot \mathrm{cm}^{-3}\right)\end{array}$} & \multirow{2}{*}{$\begin{array}{c}\text { Funnel } \\
\text { viscosity/s }\end{array}$} & \multirow{2}{*}{$\begin{array}{c}\text { FLAPI/ } \\
\mathrm{mL}\end{array}$} & \multirow{2}{*}{$\begin{array}{c}\text { FLHTHP/ } \\
\mathrm{mL}\end{array}$} & \multicolumn{2}{|c|}{ Gel strength $/ \mathrm{Pa}$} & \multirow{2}{*}{$\begin{array}{c}\mathrm{PV} / \\
(\mathrm{mPa} \cdot \mathrm{s})\end{array}$} & \multirow{2}{*}{$\mathrm{YP} / \mathrm{Pa}$} & \multirow{2}{*}{$\begin{array}{c}\mathrm{O} / \mathrm{w} \\
\text { ratio/\% }\end{array}$} & \\
\hline & & & & Starling & Expiration & & & & \\
\hline $2.30-2.50$ & $70-160$ & $<1.0$ & $<3.0$ & $4-10$ & $7-25$ & $<120$ & $6-25$ & $90 / 10$ & $>400$ \\
\hline
\end{tabular}

\subsection{Property Evaluation}

\subsubsection{Rheology and Stability Evaluation}

According to the temperature and pressure conditions of formation $\mathrm{E}_{2-3} \mathrm{a}$, before drilling the $311.1 \mathrm{~mm}$ hole section, we tested the rheology (The results are shown in Table 3) and stability (The results are shown in Table 4) of the high density oil-based drilling fluid by simulating TF (around $50^{\circ} \mathrm{C}$ ) and FMP.

Table 3. Performance evaluation under different temperature of oil-based drilling fluid.

\begin{tabular}{ccccccc}
\hline $\begin{array}{c}\text { Temperature/ } \\
{ }^{\circ} \mathrm{C}\end{array}$ & $\begin{array}{c}\text { Density/ } \\
\left(\mathrm{g} \cdot \mathrm{cm}^{-3}\right)\end{array}$ & $\begin{array}{c}\text { Apparent } \\
\text { viscosity/(mPa.s })\end{array}$ & PV/(mPa.s) & YP/Pa & Gel strength/Pa & VB/V \\
\hline 20 & 2.40 & $/$ & $/$ & $/$ & $1.5 / 1.5$ & 2047 \\
30 & 2.40 & 114 & 108 & 6 & $1.0 / 1.5$ & 1825 \\
50 & 2.40 & 73 & 75 & -2 & $1.5 / 1.5$ & 1653 \\
\hline
\end{tabular}

Table 4. Performance evaluation under different density of oil-based drilling fluid.

\begin{tabular}{cccccc}
\hline Density $/\left(\mathrm{g} \cdot \mathrm{cm}^{-3}\right)$ & Apparent viscosity $/(\mathrm{mPa} \cdot \mathrm{s})$ & $\mathrm{PV} /(\mathrm{mPa} \cdot \mathrm{s})$ & $\mathrm{VP} / \mathrm{Pa}$ & $\mathrm{Gel}$ strength/Pa & $\mathrm{VB} / \mathrm{V}$ \\
\hline 2.38 & 68 & 66 & 2 & $1.5 / 4.0$ & 2047 \\
2.50 & 94 & 92 & 2 & $2.0 / 7.0$ & 1539 \\
2.72 & $/$ & $/$ & $/$ & $4.0 / 8.0$ & 1432 \\
\hline
\end{tabular}

It can be seen in Table 2 that there is no significant change in yield stress of the oil-based drilling fluid at $30^{\circ} \mathrm{C}$ and $50^{\circ} \mathrm{C}$, which indicates that the temperature has little effect on the rheology of the oil-based drilling fluid. For temperature below $50^{\circ} \mathrm{C}$, the demulsification voltage (VB) is above $1500 \mathrm{~V}$, which shows that the oil base drilling fluid has good stability.

Table 4 is the results of the tests by increasing mud density using the iron ore powder aging tests. Results show that the oil-based drilling fluid yield stress increases to a certain degree, but the 10-minute gel strength rises insignificantly, which indicates that the oil base drilling fluid after aging still has good rheology. Based on the analysis above, the high density oil base drilling fluid is suitable for formation $\mathrm{E}_{2-3} \mathrm{a}$.

\subsubsection{Pollution Resistance Evaluation}

Considering the actual rock properties in formation $\mathrm{E}_{2-3} \mathrm{a}$ in the southern edge, $2 \%$ and $5 \%$ lime were added to the oil-based drilling fluid respectively to test the salt tolerance of the drilling fluid, and the results are shown in Table 5. 
Table 5. Stain resistance evaluation of oil-base drilling fluid.

\begin{tabular}{ccccccc}
\hline Formula & $\begin{array}{c}\text { Density/ } \\
\left(\mathrm{g} \cdot \mathrm{cm}^{-3}\right)\end{array}$ & $\begin{array}{c}\text { Apparent } \\
\text { viscosity/(mPas) }\end{array}$ & $\begin{array}{c}\mathrm{PV} / \\
(\mathrm{mPa} \cdot \mathrm{s})\end{array}$ & $\mathrm{YP} / \mathrm{Pa}$ & $\begin{array}{c}\mathrm{Gel} \\
\text { strength/Pa }\end{array}$ & $\mathrm{VB} / \mathrm{V}$ \\
\hline In-situ mud & 2.42 & 74 & 72 & 2.0 & $2.0 / 8.5$ & 2047 \\
In-situ mud + 2\% lime & 2.42 & 87 & 84 & 3.0 & $2.0 / 7.0$ & 1369 \\
In-situ mud + 5\%lime & 2.42 & 103.8 & 99 & 4.7 & $4.7 / 13.5$ & 1056 \\
\hline
\end{tabular}

According to the experimental data in Table 5, after the oil-based drilling fluid is polluted by lime, the change of the shear stress is insignificant and within the allowable range. After adding $5 \%$ lime, the VB is above $1000 \mathrm{~V}$, which indicates that the emulsion stability of the drilling fluid is still very good, and its overall performance can meet the needs of the drilling in formation $E_{2-3}$. The experimental results show that the designed oil-based drilling fluid has good pollution resistance, which can ensure the stability of the drilling fluid in the drilling process. Because the fluid is oil-based, it has excellent shale inhibition performance, and the shale recycling rate is more than $90 \%$.

\section{Field Application}

\subsection{Situation of Applications}

The high density oil-based drilling fluid was used to drill in the southern edge of well H101 $311.1 \mathrm{~mm}$ section, which is in the formation $\mathrm{E}_{2-3} \mathrm{a}$. The performance of the oil-based drilling fluid is shown in Table 6 .

Table 6. Drilling fluid performance during drilling $\mathrm{E}_{2-3}$ a formation in well $\mathrm{H} 101$.

\begin{tabular}{|c|c|c|c|c|c|c|c|c|c|c|}
\hline $\begin{array}{l}\text { Depth } \\
\text { m }\end{array}$ & $\begin{array}{l}\text { / Density/ } \\
\left(\mathrm{g} \cdot \mathrm{cm}^{-3}\right)\end{array}$ & $\begin{array}{c}\text { Funnel } \\
\text { viscosity/s }\end{array}$ & $\begin{array}{c}\text { Apparent } \\
\text { viscosity/ } \\
(\mathrm{mPa} \cdot \mathrm{s})\end{array}$ & $\begin{array}{c}\mathrm{PV} / \\
(\mathrm{mPa} \cdot \mathrm{s})\end{array}$ & $\mathrm{YP} / \mathrm{Pa}$ & $\begin{array}{l}\text { Gel } \\
\text { strength/ } \\
\mathrm{Pa}\end{array}$ & $\begin{array}{c}\mathrm{O} / \mathrm{w} \\
\mathrm{ratio} / \%\end{array}$ & Alkality/1 & $\begin{array}{c}\mathrm{VB} / \\
\mathrm{V}\end{array}$ & $\begin{array}{c}\text { Concent of } \\
\text { solid } \\
\text { phase } \%\end{array}$ \\
\hline 2050 & 2.38 & 82 & 75 & 73 & 2 & $1.5 / 2.5$ & $95 / 5$ & 0.65 & 2047 & 50 \\
\hline 2100 & 2.38 & 75 & 61 & 59 & 2 & $1.5 / 4.0$ & $95 / 5$ & 0.65 & 2047 & 50 \\
\hline 2572 & 2.42 & 80 & 85 & 82 & 3 & $2.0 / 9.0$ & $95 / 5$ & 0.65 & 2047 & 51 \\
\hline 2688 & 2.45 & 88 & 96.5 & 93 & 3.5 & $3 / 13$ & $95 / 5$ & 0.65 & 2047 & 51 \\
\hline 2810 & 2.45 & 94 & 99 & 93 & 6 & $3 / 12.5$ & $95 / 5$ & 0.65 & 2047 & 51 \\
\hline 2922 & 2.46 & 114 & 87.5 & 81 & 6.5 & $3 / 14$ & $95 / 5$ & 0.65 & 2047 & 51 \\
\hline
\end{tabular}

After the oil-based drilling fluid was pumped into the well, the drilling of the cement plug at the measured depth of $2014 \mathrm{~m}$ started. After drilling down to 40 $\mathrm{m}$, the drill bit entered the new formation. During the process of drilling the cement plug, the funnel viscosity of the oil-based drilling fluid decreased to $70 \mathrm{~s}$ due to the increase of temperature, and the other properties remained unchanged. Upon drilling down to $2068 \mathrm{~m}$, the drill string was pulled out of the well to change the PDC bit. The average rate of the penetration was $5-8 \mathrm{~min} / \mathrm{m}$, and the weight on bit was $80-100 \mathrm{kN}$. Because of the fast drilling speed, the 
drilling fluid density was increased to $2.42 \mathrm{~g} / \mathrm{cm}^{3}$ at around $2200 \mathrm{~m}$, which was prepared for passing the first fault point. The first fault was drilled through successfully with normal cuttings return (Figure 1) and no appearance of washouts.



Figure 1. The upper strata returns drilling cutting of $\mathrm{E}_{2-3} \mathrm{a}$.

Based on the analysis of the drilling problems during the drilling of the middle part of formation $\mathrm{E}_{2-3} \mathrm{a}$, it was concluded that besides the hydrate expansion and dispersion of the mudstone, the formation fracture caused at the second fault point also caused a lot of drilling difficulties. Thus, at the depth of $2640 \mathrm{~m}$, the density of the drilling fluid was increased to $2.44 \mathrm{~g} / \mathrm{cm}^{3}$, meanwhile, the concentration of the blocking agent and the fluid loss control agent were increased to enhance the performance of blockage and prevent the lost circulation. When drilling down to $2640 \mathrm{~m}$, the reciprocation was performed to ensure the smoothness of the well. The back reaming was performed during $2650-2540 \mathrm{~m}$ and the well was smooth.

During the drilling of the middle and lower part of formation $\mathrm{E}_{2-3} \mathrm{a}$, although the well was drilled by drilling down to $1 \mathrm{~m}$ and back reaming $3 \mathrm{~m}$ tight spots still occurred during the tripping-out. However, the tripping process was smooth. According to the analysis, it may be caused by the brown mudstone at the lower part of the formation, which is softer than the upper green mudstone that can lead to the hole shrinkage easier. Because of that, the density of the drilling fluid was increased to $2.46 \mathrm{~g} / \mathrm{cm}^{3}$ at the depth of $2850 \mathrm{~m}$. After that, the phenomenon mentioned above disappeared. The returned cuttings at the shale shaker were normal and no wash-out appeared.

\subsection{Drilling Fluid Dispose and Maintenance}

1) During the mixing of the drilling fluid, the pre-designed were followed strictly. After adding the materials, the fluid was stirred well to make it dissolve evenly. Upon being finished, the high temperature rolling experiment was per- 
formed. Appropriate adjustment was made, based on the test results.

2) In order to maintain consistant performance, routine tests were performed 4 times a day, and the corresponding amounts of additives were adjusted timely according to the test results. The electric stability of system should be kept above $400 \mathrm{~V}$ at $50^{\circ} \mathrm{C}$.

3) If the mud viscosity is too high, the reasons for the increase of viscosity should be analyzed in time. The stability of the fluid can be maintained by increasing the oil-water ratio (the-oil-water ratio should be in the range of 95/5 98/2) and adding emulsifier and moderate lime.

4) The filtration loss of HTHP should be controlled within $3 \mathrm{ml}$ by adding fluid loss agent and blocking agent.

5) Adjusting drilling fluid density in real time based on the cuttings returned on the shale shaker. When the large wash-out appears, the density of the drilling fluid is increased properly by adding barite. At the same time, the wetting agent and emulsifier need to be added.

\subsection{Application Results}

Well H10, well H001, well H002 are three adjacent wells of well H101. The potassium polysulfonate PRT drilling fluid system and the potassium calcium based PRT drilling fluid system were used in $311.1 \mathrm{~mm}$ hole section of well H10 and well H001, respectively. Complex accidents occurred at high frequency in hole section $311.1 \mathrm{~mm}$ of both wells. When the organic salt drilling fluid system (The amount of organic salt was up to $40 \%$ - 50\%) was used in hole section 311.1 mm of well H002, complex accidents also occurred. However, when the high density oil-based drilling fluid was used in the same section of well H101, no accidents occurred, and for the first time, the $\mathrm{E}_{2-3}$ a formation was able to be drilled through in one trip. The statistics results of the accidents of well H101 and adjacent wells in formation $\mathrm{E}_{2-3}$ a are shown in Table 7.

Table 7. Complex accident contrast in $\mathrm{E}_{2-3} \mathrm{a}$ of $\mathrm{H} 101$ well with adjacent wells.

\begin{tabular}{cccc}
\hline Well No. & Depth/m & Type of complex accident & Waste time/d \\
\hline H10 & $1826-2982$ & Sticking 9, loss 3 & 104 \\
H001 & $2071-2872$ & Sticking 4 & 90 \\
H002 & $1843-3095$ & Sticking 1 & 12 \\
H101 & $2050-2904$ & No sticking & 0 \\
\hline
\end{tabular}

The length of section $311.1 \mathrm{~mm}$ of well H101 is $872 \mathrm{~m}$, and the total drilling time for section $311.1 \mathrm{~mm}$ is only $6.9 \mathrm{~d}$. The AROP of section $311.1 \mathrm{~mm}$ is 11.65 $\mathrm{m} / \mathrm{h}$, increasing by $763 \%$ compared to adjacent wells. The well construction time of adjacent wells is above 100 days in $311.1 \mathrm{~mm}$ section. Compared with adjacent wells, the construction period of well H101 was reduced by more than 4/5, which greatly reduced the drilling cost and achieved historic breakthrough of drilling speed in the Southern Edge [9]-[15]. The ROP and construction time comparison in $311.1 \mathrm{~mm}$ of H101 well with adjacent wells are shown in Figure 2. 


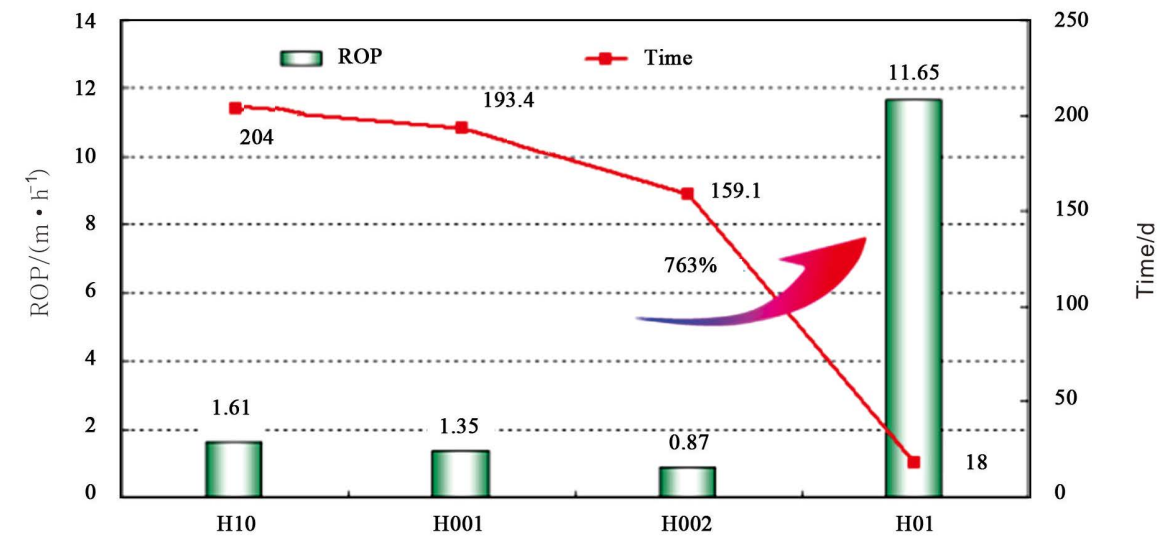

Figure 2. ROP and construction period contrast in $311.1 \mathrm{~mm}$ of $\mathrm{H} 101$ well with adjacent wells.

\section{Conclusions}

Through the laboratory studies and field applications, the following conclusions can be reached:

1) The main difficulties of drilling in southern edge of Xinjiang are strong water sensitivity, high horizontal stress, high formation pressure gradient, and borehole instability. Lost circulation, blow-out, borehole collapse, drill pipe stuck are easy to happen. For a long time, the AROP is lower than $3 \mathrm{~m} / \mathrm{h}$, and the drilling fluid system cannot meet the needs of drilling applications.

2) A high density oil-based drilling fluid with strong anti-pollution ability, good lubricity and inhibition was developed for formation $\mathrm{E}_{2-3} \mathrm{a}$ in the southern area by the laboratory study. Through the field tests, a set of mature processing technology has been developed, and its performance can be well adapted to meet the needs of the complex structure of the Piedmont tectonic in the southern edge, and the formula of the drilling fluid is relatively simple and easy to maintain.

3) The application of high density oil-based drilling fluid in the southern Piedmont has achieved good results. The drilling mud performs well in maintaining the borehole stability, and it is a good solution to the problems of strong water sensitivity of formation $\mathrm{E}_{2-3} \mathrm{a}$. However, the application time of the system in the southern edge is very short, the cost of oil-based drilling fluid is much higher than that of the water-based drilling fluid, and its impact on the environment is much severer than water-based fluids.

\section{Conflicts of Interest}

The authors declare no conflicts of interest regarding the publication of this paper.

\section{References}

[1] Liang, D.C., Li, J., et al. (1997) The Discussion of Anti-Sloughing Drilling Fluid in the Southern Margin of Junggar Basin Area. Petroleum Drilling Techniques, 25, 24-26. 
[2] Liu, S.H. (2013) Drilling Fluid Technologies for Complex Formations of Nanyuanshanqian Structure in Junggar Basin. Petroleum Drilling Techniques, 31, 33-34.

[3] Zhang, B., Zhang, M., Li, T.T., et al. (2008) Quantitative Evaluation of Factors Influencing Filtrate Loss of High Density Mud. Oil Drilling \& Production Technology, 30, 52-55.

[4] Zhang, Y., Zhang, B., Wu, Z.L., et al. (2013) Application of Oil-Based Drilling Fluid in Ultra Deep Wells Complex. Drilling \& Production Technology, 36, 95-97.

[5] Wang, Y.Z, Luo, C.Z., Shi, J.G., et al. (2003) Study on Synthetic Drilling Fluids for Reservoir Protection. Petroleum Drilling Techniques, 31, 31-32.

[6] Wan, X.X. (2013) Oil-Based Drilling Fluid Applied in Drilling Shale Oil Reservoirs in Bonan Block. Petroleum Drilling Techniques, 41, 44-50.

[7] Liu, Y.F. (2007) Tcchnological Difficulties and Application of High Density Drilling Fluid. Exploration Engeering, 34, 47-49.

[8] Wang, J.L., Hei, G.X. and Zhao, H.X. (2012) Dilling \& Completion Techniques Used in Shale Gas Horizonal Well YSH1-1 in Zhaotong Block. Petroleum Drilling Techniques, 40, 23-27.

[9] Cai, L.S., Lin, Y.X., Yang, X.H., et al. (2013) Ultra-High Density Drilling Fluid Technology in Well Guanshen1. Journal of Petroleum, 34, 169-177.

[10] Zhang, W., Liu, Z.D., Liu, B.F., et al. (2008) Popularization and Recycling of Oil-Based Drilling Fluid. Petroleum Drilling Techniques, 36, 34-38.

[11] Luo, L.G., Guan, Z.C., Su, C.M., et al. (1997) The Application of Oil-Based Drilling Fluid in the Special Drilling. Drilling \& Production Technology, 20, 71-74.

[12] Wang, Z.H. (2011) Status and Development Trend of Ultra-High Temperature and High Density Drilling Fluid at Home and Abroad. Petroleum Drilling Techniques, 39, 1-7.

[13] Wang, Z.H. (2011) The Drilling Technology Progress and the Understanding of Drilling Fluid at Home and Abroad. Sino-Global Energy, 16, 48-60.

[14] He, Z.K. (2012) Oil Base Drilling Fluid Technology Applied in Well Biye HF1. Petroleum Drilling Techniques, 40, 32-37.

[15] Wang, X.G., Li, X. and Lin, Y.X. (2013) Research and Application of High Performance Oil Base Drilling Fluid for Shale Horizonal Wells. Petroleum Drilling Techniques, 41, 17-22. 